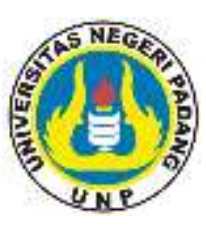

\title{
ANALISIS KEMAMPUAN PENGGUNAAN JODOUSHI SOUDA DAN YOUDA PADA MAHASISWA TAHUN MASUK 2017 PROGRAM STUDI PENDIDIKAN BAHASA JEPANG UNIVERSTAS NEGERI PADANG
}

\section{Gita Maharani ${ }^{1}$, Nova Yulia ${ }^{2}$}

Program Studi Pendidikan Bahasa Jepang ${ }^{1}$ (Jurusan Bahasa dan Sastra Inggris, Fakultas Bahasa dan Seni, Universitas Negeri Padang)

Program Studi Pendidikan Bahasa Jepang ${ }^{2}$ (Jurusan Bahasa dan Sastra Inggris, Fakultas Bahasa dan Seni, Universitas Negeri Padang)

Email Penulis : gitam828@ gmail.com

\section{Sejarah Artikel \\ Submit : 2019-7-24 \\ Diterima : 2019-8-19 \\ Diterbitkan : 2019-08-30}

\section{Kata Kunci: jodoushi, souda, youtai, youda, futashikana dantei}

\begin{abstract}
Abstrak
This research discusses the ability of the 2017 Japanese Students in using jodoushi souda and youda on Japanese Education Study Program at Universitas Negeri Padang. This research was aimed at describing the ability of the 2017 Japanese Students in using jodoushi souda and youda on Japanese Education Study Program at Universitas Negeri Padang. The type of research used in this study is quantitative research with descriptive methods. The population in this study was the 2017 Japanese Students on Japanese Education Study Program at Universitas Negeri Padang amounting 56 students consisting of two classes. Japanese Class 1 consisted of 29 students and Japanese Class 2 consisted of 27 students. The data in this study are scores of students' 2017 jodoushi souda and youda ability test results in Japanese Education Study Program at Universitas Negeri Padang. Based on the results of the research conducted it can be concluded that the ability of jodoushi souda and youda in general in the "less" qualification with an average of 46,57 .
\end{abstract}

\section{PENDAHULUAN}

Bahasa menurut Kridalaksana (dalam Monika 2017:1) adalah sistem simbol bunyi yang bermakna dan berartikulasi (dihasilkan oleh alat ucap) yang bersifat arbitrer dan konvensional, yang dipakai sebagai alat berkomunikasi oleh sekelompok manusia untuk melahirkan perasaan dan pikiran.

Saat ini di Indonesia, ada tiga kategori bahasa yang diajarkan di institusi pendidikan, yaitu bahasa daerah, yang merupakan bahasa ibu yang dipergunakan secara terbatas pada suatu suku-bangsa; bahasa Indonesia yang merupakan bahasa nasional yang dipergunakan sebagai lingua franca di sekolah, pemerintahan dan kantor-kantor swasta, serta bahasa asing yang dipergunakan untuk berkomunikasi

\footnotetext{
${ }^{1}$ Mahasiswa Prodi Pendidikan Bahasa Jepang FBS UNP lulus pada September 2019

2 Dosen Prodi Pendidikan Bahasa Jepang FBS UNP
} 
dengan komunitas orang asing. Di antara bahasa asing yang diajarkan adalah bahasa Jepang. Bahasa Jepang merupakan bahasa yang unik. Sebagaimana Sudjianto dan Dahidi (dalam Khairani 2018: 2) mengatakan bahwa keunikan bahasa Jepang dapat dilihat dari huruf dan tata bahasa yang berbeda dari bahasa negara lain.

Dalam bahasa Jepang banyak terdapat kata yang memiliki fungsi yang mirip tetapi gramatikal nya berbeda. Seperti kata bantu verba Jodoushi Souda dan Youda. Kedua kata tersebut berfungsi untuk menunjukkan perkiraan dan menunjukkan suatu informasi dari media seperti dari koran, televisi, maupun dari pembicaraan seseorang. Yang dalam bahasa Indonesia dapat diartikan 'sepertinya' atau 'tampaknya'. Meskipun dalam bahasa Indonesia kata Souda dan Youda dapat diartikan dengan kata yang sama, namun sebenarnya kata Souda dan Youda memiliki perbedaan makna dan penggunaan. Seperti yang terlihat pada contoh dibawah ini.

a) あしたは熱くなりそうです。

(Souda)

Ashita wa atsuku narisoudesu.

Kelihatannya besok cuacanya akan menjadi panas.

b) 部長は甘い物がすきなようです。

$($ Youda $)$

Buchouwa amaimonoga sukina youdesu.

Sepertinya direktur suka makanan manis.

Seperti yang terlihat pada contoh di atas, kedua kata tersebut sama-sama menyatakan suatu peristiwa berupa dugaan yang mana contoh a) dinyatakan dengan 'kelihatannya' dan contoh b) dinyatakan dengan 'sepertinya'. Pada contoh a) menggunakan kata bantu verba souda yang mana si pembicara kemungkinan melihat ramalan cuaca yang menyatakan besok cuacanya akan panas. Sedangkan pada contoh b) menggunakan kata bantu verba youda yang mana si pembicara menyatakan kemungkinan direktur nya menyukai makanan manis yang kemungkinan si pembicara sering melihat direktur nya memakan makanan manis.

Bagi pembelajar bahasa Jepang, mungkin akan sedikit kesulitan dalam membedakan Souda dan Youda. Butuh pemahaman yang mantap agar pembelajar memahami perbedaan Souda dan Youda secara baik. Selain itu penulis juga sempat merasakan kebingungan dalam memahami perbedaan makna pada Jodoushi Souda dan Youda ini. Berdasarkan penelitian Lidra (2018), hasil penelitian menyatakan bahwa kemampuan penggunaan jodoushi -souda pada mahasiswa tingkat III Program Studi Bahasa Jepang Universitas Negeri Padang berada pada kualifikasi "kurang" pada rentang nilai 40-49 dengan rata-rata 42,41.

Penulis ingin mengetahui bagaimana kemampuan penggunaan Jodoushi Souda sebagai youtai dan Youda sebagai futashikana dantei ini pada mahasiswa tahun masuk 2017 Prodi Pendidikan Bahasa Jepang Universitas Negeri Padang dikarenakan bila melihat kurikulum Program Studi Pendidikan Bahasa Jepang, mahasiswa yang bersangkutan sedang mengambil mata kuliah Shocukyu Bunpou Kohan yang mana salah satu materinya adalah mengenai Souda dan Youda tersebut. Oleh karena itu penulis ingin membahas kata bantu verba Jodoushi Souda dan Youda 
yang mempunyai makna "sepertinya/kelihatannya/rupa-rupanya" dengan judul 'Analisis Kemampuan Penggunaan Jodoushi Souda dan Youda pada mahasiswa tahun masuk 2017 Program Studi Pendidikan Bahasa Jepang Universitas Negeri Padang'.

\section{METODE PENELITIAN}

Jenis penelitian ini adalah penelitian deskriptif. Sugiyono (2009:63) mengemukakan bahwa metode deskriptif adalah suatu metode yang digunakan untuk meneliti status kelompok manusia, suatu objek, suatu kondisi, suatu sistem pemikiran ataupun suatu strata, peristiwa pada masa sekarang. Data dari penelitian ini adalah skor tes kemampuan jodoushi souda dan youda mahasiswa tahun masuk 2017 Program Studi Pendidikan Bahasa Jepang Universitas Negeri Padang. Sedangkan sumber data yang diambil adalah buku teks Minna no Nihongo Shokyuu II Bab 43 dan 47.

Instrumen dalam penelitian ini adalah soal objektif berbentuk pilihan ganda dan isian pendek untuk mengukur kemampuan jodoushi souda dan youda. Menurut Sutedi (2011:155), instrumen penelitian yaitu alat yang digunakan untuk mengumpulkan atau menyediakan berbagai data yang diperlukan dalam kegiatan penelitian. Instrumen yang digunakan dalam penelitian ini adalah tes. Tes merupakan alat ukur yang biasanya digunakan untuk mengukur hasil belajar siswa setelah selesai satu satuan program pengajaran tertentu (Sutedi, 2011:157).

Adapun teknik pengumpulan data sebagai berikut. Pertama, memberikan soal tes objektif untuk mengetahui kemampuan penggunaan jodoushi souda dan youda sesuai waktu yang diberikan. Kedua, Mahasiswa ditugasi menjawab tes yang telah disediakan. Ketiga, Mengumpulkan lembar jawaban mahasiswa dan memeriksa hasil dari lembar jawaban tersebut. Keempat, Memberikan skor pada lembar jawaban dan mengubah skor menjadi nilai. Kemudian dilanjutkan dengan menganalisis data dengan langkah sebagai berikut. Pertama, menentukan nilai rata-rata hitung. Kedua, membuat sebaran data secara ilmiah. Ketiga, mengklasifikasikan nilai per indikator. Keempat, mengklasifikasikan nilai kemampuan menggunakan jodoushi souda dan youda mahasiswa Program Studi Pendidikan Bahasa Jepang Universitas Negeri Padang berdarkan skala 10. Kelima, pembahasan temuan. Terakhir, kesimpulan.

\section{HASIL DAN PEMBAHASAN}

\section{Temuan Penelitian}

Berdasarkan analisis terhadap skor tes, kemampuan penggunaan jodoushi souda dan youda secara keseluruhan, kemampuan penggunaan jodoushi souda sebagai youtai dan kemampuan penggunaan jodoushi youda sebagai futashikana dantei mahasiswa tahun masuk 2017 Program Studi Pendidikan Bahasa Jepang Universitas Negeri Padang sebagai berikut. 


\section{Tabel Nilai Rata-Rata Kemampuan Penggunaan Jodoushi Souda dan Youda Mahasiswa Tahun Masuk 2017 Program Studi Pendidikan Bahasa Jepang Universitas Negeri Padang}

\begin{tabular}{|l|c|c|}
\hline Rata-Rata & 47,09 & Kurang \\
\hline $\begin{array}{l}\text { Nilai } \\
\text { Tertinggi }\end{array}$ & $\mathbf{8 0}$ & Sangat Baik Sekali \\
\hline $\begin{array}{l}\text { Nilai } \\
\text { Terendah }\end{array}$ & 10 & Gagal \\
\hline
\end{tabular}

Berdasarkan tabel di atas diketahui nilai rata-rata kemampuan penggunaan jodoushi souda dan youda mahasiswa tahun masuk 2017 Program Studi Pendidikan Bahasa Jepang Universitas Negeri Padang yang diperoleh dari 56 orang mahasiswa adalah 47,09 dengan kualifikasi kurang. Nilai tertinggi yang diperoleh mahasiswa adalah 80 dengan kualifikasi sangat baik sekali dan nilai terendah yang diperoleh mahasiswa adalah 10 dengan kualifikasi gagal.

\section{Pembahasan}

Sebagaimana telah dideskripsikan, hasil analisis data menunjukkan secara keseluruhan kemampuan penggunaan jodoushi souda dan youda mahasiswa tahun masuk 2017 Program Studi Pendidikan Bahasa Jepang Universitas Negeri Padang memiliki rata-rata 46,57 dengan kualifikasi kurang. Dalam penelitian ini, dapat diketahui kemampuan penggunaan jodoushi souda dan youda dari tiga indikator yang dinilai. Indikator tersebut adalah (1) mengidentifikasi penggunaan jodoushi souda sebagai youtai dan youda sebagai futashikana dantei yang tepat pada kalimat bahasa Jepang, (2) mengidentifikasi penggunaan kata kerja/kata benda/kata sifat yang mengikuti kata jodoushi souda sebagai youtai dan youda sebagai futashikana dantei, (3) mengubah kalimat biasa ke kalimat yang menggunakan jodoushi souda sebagai youtai dan youda sebagai futashikana dantei. Dalam penelitian ini diketahui tiga hal sebagai berikut.

Pertama, kemampuan penggunaan jodoushi souda dan youda mahasiswa tahun masuk 2017 Program Studi Pendidikan Bahasa Jepang Universitas Negeri Padang untuk indikator mengidentifikasi penggunaan kata bantu verba souda sebagai youtai dan youda sebagai futashikana dantei yang tepat pada kalimat bahasa Jepang dengan rata-rata 51,43. Kedua, kemampuan penggunaan jodoushi souda sebagai youtai mahasiswa tahun masuk 2017 Program Studi Pendidikan Bahasa Jepang Universitas Negeri Padang untuk indikator mengidentifikasi penggunaan kata bantu verba souda sebagai youtai dan youda sebagai futashikana dantei yang tepat pada kalimat bahasa Jepang dengan rata-rata 67,00. Ketiga, kemampuan penggunaan jodoushi youda sebagai futashikana dantei mahasiswa tahun masuk 2017 Program 
Studi Pendidikan Bahasa Jepang Universitas Negeri Padang untuk indikator mengidentifikasi penggunaan kata bantu verba souda sebagai youtai dan youda sebagai futashikana dantei yang tepat pada kalimat bahasa Jepang dengan rata-rata 44,63. Keempat, kemampuan penggunaan jodoushi souda dan youda mahasiswa tahun masuk 2017 Program Studi Pendidikan Bahasa Jepang Universitas Negeri Padang untuk indikator mengidentifikasi penggunaan kata kerja/kata benda/kata sifat yang mengikuti kata bantu verba souda dan dan youda dengan rata-rata 52,14. Kelima, kemampuan penggunaan jodoushi souda sebagai youtai mahasiswa tahun masuk 2017 Program Studi Pendidikan Bahasa Jepang Universitas Negeri Padang untuk indikator mengidentifikasi penggunaan kata kerja/kata benda/kata sifat yang mengikuti kata bantu verba souda dan dan youda dengan rata-rata 57,14. Keenam, kemampuan penggunaan jodoushi youda sebagai futashikana dantei mahasiswa tahun masuk 2017 Program Studi Pendidikan Bahasa Jepang Universitas Negeri Padang untuk indikator mengidentifikasi penggunaan kata kerja/kata benda/kata sifat yang mengikuti kata bantu verba souda dan dan youda dengan rata-rata 50,29. Ketujuh, kemampuan penggunaan jodoushi souda dan youda mahasiswa tahun masuk 2017 Program Studi Pendidikan Bahasa Jepang Universitas Negeri Padang untuk indikator mengubah kalimat biasa ke kalimat yang menggunakan kata bantu verba souda dan youda dengan rata-rata 37,68. Kedelapan, kemampuan penggunaan jodoushi souda sebagai youtai mahasiswa tahun masuk 2017 Program Studi Pendidikan Bahasa Jepang Universitas Negeri Padang untuk indikator mengubah kalimat biasa ke kalimat yang menggunakan kata bantu verba souda dan youda dengan rata-rata 56,59. Kesembilan, kemampuan penggunaan jodoushi youda sebagai futashikana dantei mahasiswa tahun masuk 2017 Program Studi Pendidikan Bahasa Jepang Universitas Negeri Padang untuk indikator mengubah kalimat biasa ke kalimat yang menggunakan kata bantu verba souda dan youda dengan rata-rata 29,61. Berdasarkan analisis data di atas, diketahui bahwa indikator mengidentifikasi penggunaan kata bantu verba souda dan youda yang tepat pada kalimat bahasa Jepang merupakan indikator yang kurang dikuasai. Hal ini disebabkan karena sampel kurang memahami kalimat yang seharusnya diikuti souda dan kalimat yang seharusnya diikuti youda

Untuk indikator mengidentifikasi penggunaan kata kerja/kata benda/kata sifat yang mengikuti kata bantu verba souda dan youda merupakan indikator yang paling dikuasai. Dari contoh lembar jawaban mahasiswa pada analisis data tersebut secara umum mampu memahami kata kerja/kata benda/kata kerja yang mengikuti souda sebagai youtai dan youda sebagai futashikana dantei.

Sedangkan indikator mengubah kalimat biasa ke kalimat yang menggunakan kata bantu verba souda dan youda merupakan indikator terendah yang dikuasai. Hat tersebut disebabkan kurang pahamnya mahasiswa dalam mengubah kalimat biasa ke dalam kalimat yang diikuti souda dan youda. Dan karena soal pada indikator tersebut adalah soal isian maka mahasiswa merasa kesulitan karena tidak terbantu seperti soal pilihan ganda.

Jika dikaji ulang dengan penelitian relevan, hasil penelitian ini hampir sama dengan penelitian yang dilakukan oleh Harviko Lidra (2018) dengan judul "Kemampuan Penggunaan Jodoushi Souda pada mahasiswa tingkat III Pendidikan 
Bahasa Jepang Universitas Negeri Padang”, dari hasil penelitian ditemukan bahwa pemahaman mahasiswa terhadap penggunaan jodoushi souda adalah kurang dengan rata-rata 42,41 .

\section{KESIMPULAN}

Berdasarkan hasil analisis data penelitian yang telah dilakukan, dapat disimpulkan hal berikut.

a. Kemampuan penggunaan jodoushi souda dan youda pada mahasiswa tahun masuk 2017 Program Studi Pendidikan Bahasa Jepang Universitas Negeri Padang berada pada kualifikasi "kurang" pada rentang nilai 40-49 dengan ratarata 46,57.

b. Kemampuan penggunaan jodoushi souda dan youda pada mahasiswa tahun masuk 2017 Program Studi Pendidikan Bahasa Jepang Universitas Negeri Padang untuk indikator mengidentifikasi penggunaan kata bantu verba souda sebagai youtai dan youda sebagai futashikana dantei yang tepat pada kalimat bahasa Jepang berada pada kualifikasi "kurang cukup" pada rentang nilai 50-59 dengan rata-rata 51,43.

c. Kemampuan penggunaan jodoushi souda dan youda mahasiswa tahun masuk 2017 Program Studi Pendidikan Bahasa Jepang Universitas Negeri Padang untuk indikator mengidentifikasi penggunaan kata kerja/kata benda/kata sifat yang mengikuti kata bantu verba souda dan dan youda berada pada kualifikasi "kurang cukup" pada rentang nilai 50-54 dengan rata-rata 52,14.

d. Kemampuan penggunaan jodoushi souda dan youda mahasiswa tahun masuk 2017 Program Studi Pendidikan Bahasa Jepang Universitas Negeri Padang untuk indikator mengubah kalimat biasa ke kalimat yang menggunakan kata bantu verba souda dan youda berada pada kualifikasi "gagal" pada rentang nilai $\leq 39$ dengan rata-rata 37,68 .

\section{REFERENSI}

Khairani, Miftahul dan Yulia, Nova dan Putri, Meira Anggia. "Analisis Pembentukan Fukugougo dalam novel Harii Potta To Kenja No Ishi Karya J.K Rowling”. Jurnal. Padang: Universitas Negeri Padang.

Lidra, Harviko. 2018. "Kemampuan Penggunaan Jodoushi -Souda pada mahasiswa tingkat III Pendidikan Bahasa Jepang Universitas Negeri Padang”. Skripsi. Padang : Universitas Negeri Padang.

Monika, Rika. 2017. "Analisis Perbedaan Nuansa Makna dari Kata 'Soudesu dan Youdesu' dalam Kalimat Bahasa Jepang yang terdapat dalam Majalah Nipponia". Skripsi. Medan: Universitas Sumatera Utara.

Sugiyono. 2009. Metode Penelitian Pendidikan.Bandung : Alfabeta.

Sutedi, Dedi. 2011. Penelitian Pendidikan Bahasa Jepang. Bandung : UPI Press.

Tarigan, Henry Guntur. 2011. Pengajaran Kosakata. Bandung: Angkasa. 
Tito, Reza Muhammad. 2016. "Efektivitas Penggunaan Media Lagu Berbahasa Jepang Pada Pembelajaran Kosakata Dalam Bahasa Jepang”. Skripsi. Fakultas Pendidikan Bahasa dan Sastra.Universitas Pendidikan Indonesia.

Zalman, Hendri. 2014. Kosakata Bahasa Jepang Dasar. Padang: FBS UNP Press. 